\title{
Bottlenecks of the Chinese Power Reform Innovation
}

\author{
Yang Liu* \\ School of Law, South China University of Technology, Guangzhou 510006, China \\ *corresponding author
}

Keywords: Power Reform; Innovation; Bottleneck; Universal Service.

\begin{abstract}
Reforms inside the Chinese power grid sector are now the highlights in the Chinese law research. The main objective of the reform is to create a market, in which competition among different power generation companies will be available. The System Reform Plan in Electricity Industry is a milestone in the electricity industry reform. On the other side, has also shown its bottlenecks to the reform innovations. Because the state-owned power corporations cannot deploy flexible pricing mechanism; function of market has not totally made available in the energy sector.
\end{abstract}

\section{Introduction}

Reforms inside the Chinese power grid sector are now the highlights in the Chinese law research. The grid charge formulation in China was affected by the traditional socialist economy. The Chinese central government still wants to control the national economy with state-owned undertakings. In many industries, the state has even strengthened its control or has banished involvements of private companies. A good example is the re-nationalization of privatized Lu Neng Group in Shandong Province. Meanwhile the so called "Socialist Economic Principle" required in Article 1 and 6 Chinese Constitution is the precondition of state ownership domination in the energy industry. State ownership ensures the governmental involvement in the national economy. As the state ownership of electric networks is politically decided by the national economic security, the Chinese central government has not allowed the privatization of electric networks to happen. However, it became obvious that state-owned electricity industry lacks efficiency. This has forced the central government to open the market, which is politically called the "socialist market with Chinese character". The reform is to increase the efficiency of power generation and create a stateowned grid operator. The efficiency improvement of networks is not directly included in the reform, since the state owned grid operator is still vertically integrated. Especially, distribution network operators are vertically integrate in the electricity power companies.

\section{Goal of the Reforms}

The main objective of the reform is to create a market, in which competition among different power generation companies will be available. However the bottom line is that the electricity retail market will be still monopolized by the electricity power companies. On 10th February 2002, the Chinese central government published the "System Reform Plan in Electricity Industry", in order to limit the systematical shortcoming of monopolized business mode and to overcome the barriers among provincial electricity markets. The System Reform Plan in Electricity Industry has formulated criteria for the reform, which should raise the network efficiency and reduce the cost of network operation. The standardized principle "efficiency improvement and cost reduction" illustrates the reform objective, and has been always cited in other official documents.

The reform is implemented under the socialist doctrines. The socialist doctrines are required by the Chinese Constitution (Article 1, 6 and 15). According to Article 6 Chinese Constitution, the basis of the socialist economic system of the People's Republic of China is socialist public ownership of the means of production. The state, according to Article 15 Chinese Constitution, practices economic planning on the basis of socialist public ownership. Based on the requirements of the Chinese Constitution, grid industry will be owned by the state. However, the state will only 
apply the economic planning to implement the public ownership. It means that those state-owned grid companies have the power of decision-making in operation and management.

\section{Reform in Power Pricing Sectors}

Scheme in pricing section will reform the electricity product price. As mentioned before, electricity generation companies are market competitors. Price of electricity product will obey the market competition principles.

\subsection{Capacity Tariff and Quantity Tariff}

Because of the reform, purchase of electricity products becomes more complicated. Before the reform takes place, electric power will be just produced by vertically integrated power plants to meet provincial electricity demands. Purchase of electricity products between provincial electric power company and its owned power plants is easy. After the reform, if vertically integrated power plants cannot provide demanded quantity of electric power, provincial electric power companies have to buy electricity products from electricity generation companies.

Contents of electricity purchase price paid by the vertically integrated provincial electric power companies have therewith changed. It includes two sub-categories. One is electricity price for vertically integrated power plants; the other is electricity products' price for electricity generation companies, which is formulated in the market. Those two prices are different but both are decisive for the electricity retail price for end consumers. When electricity price for electricity generation companies gets higher, it will force provincial electric power companies to raise the retail price.

In order to avoid market risk and ensure safe and stable electricity supply, price of electricity products will be regulated. Instrument of the regulation is the "capacity tariff", which is the fixed electricity price calculated by vertically integrated power plants. The capacity tariff is decided by the power generation capacity of vertically integrated power plants. The capacity tariff will be permitted by the government and called as the "on-grid tariff". Retailing price of electricity will be coupled with on-grid tariff.

At the same time, price of electricity will be determined in the Electricity Exchange. In the regulation, it is called "quantity tariff". Quantity tariff will not be regulated by the government. It is determined by the bidding. Bidding in spot market could involve partial electricity generated by power plant or all electricity generated. For fair business of electricity products, bidding rules in the regional market shall be identical.

\subsection{Electricity Exchange and Trade}

One important step of reform in the price sector is the establishment of the Electricity Exchange. The electricity exchange is the spot market of electricity. Electricity generation companies are forced to sell electricity products in the market. Electricity Exchange is the market, which is created by the establishment of regional grid companies. Generally, each regional grid company will establish and operate one Electricity Exchange. The regional grid company will take the responsibility to organize the Electricity Exchange. In order to build a national wide electricity market, each Electricity Exchange shall be open to the others. Electricity generation companies are the sellers of electricity in the Exchange, and provincial electric power companies are the buyers. Duty of the Electricity Exchange is to provide the platform of trade.

For the trade of electricity, quantity tariff, namely price of electricity products, will be determined in methods of contract trade, store trade and future trade. Generally, the contract trade is established with the long-term contract between market entities (buyer and seller). It fulfills different electricity supply periods like week, month, quarter or a year. The store trade is decided by the auction of electricity produced within 24 hours, which serves to stabilize the daily electricity supply. The Future trade handles electricity produced in the coming 24 hours. Generally, contract trade is the primary part, which is associated with store and future trades. Following graphic show the models of electricity trade in China. Grid operators shall provide stabilized network service and ensure the safety of electricity transmission. 
It should be noticed that the System Reform Plan in Electricity Industry has brought high market risk to electricity generation companies. For example, price of coal has been dramatically increased in 2008. The over invested electricity generation sector in China could not keep its business profits, because under the market competition price of electricity products was not increased. As a result, many electricity generation companies had to change their plans of reinvestment. Growth of national electricity generation capacity was slow down.

\section{Bottlenecks to Reform Innovation}

The System Reform Plan in Electricity Industry is a milestone in the electricity industry reform. The ex-State Electricity Corporation was dismantled into several self managed juridical persons in different energy sectors. Regional grid companies in the market of electricity products were created by the System Reform Plan in Electricity Industry. Under the pressure of market competitions, they will deliver low priced electricity products (quantity tariff). Profit level of electricity generation companies will be decided by the quantity of their sold electricity products. As quantity tariff connects with the retail price of electricity, end consumers in China can also make profits from this reform. It is a positive development of national electricity industry in China.

This reform, on the other side, has also shown its bottlenecks to the reform innovations. First, the separation of ex- State Electricity Corporation had reduced network efficiency. The State Electricity Corporation owned and operated a national united electricity networks. After the disintegration, there are even two uncombined grid corporations (State Grid Corporation China and China Southern Grid Corporation), which operate their owned electricity networks. The second shortage of this reform is that provincial electric power companies are much powerful in the market than regional grid corporations (regional grid companies); because they monopolize the electricity retailing market and could even decide the retailing price of electricity. The central government has lost its direct control of electricity distribution, because electricity distribution networks are owned by provincial electric power companies. Second, as the Chinese statutes require the independent management of state-owned companies, the provincial electric power companies will not be controlled by the central government. The state is just responsible for the financial supervision of those state-owned companies. Provincial electric power companies will manage and operate their owned electricity distribution networks independently. The planned functions of regional grid companies could not been fulfilled, since they are more like small sized state grid corporations and their business managements must cooperate with provincial electric power companies. It leads the central government to provide further reforms, in which distribution network operators must be absolutely separated from transmission network operators and urban electric networks must be independent from its regional parent companies. As provincial electric power companies are still vertically integrated electricity suppliers, the level of market competition will be dramatically decreased.

\section{Conclusion Comments}

In the theory of regulatory laws, market opening set by the government shall firstly obey the general principles of market economy. It means that the regulator should provide the market players their freedoms in business areas. The price of certain product or service should be determined by the costs of market operators.

Thus, the reforms inside the Chinese power grid sector, although it has provided the market opening regimes, has created the bottlenecks of market reforms. The state-owned power corporations cannot deploy flexible pricing mechanism; function of market has not totally made available in the energy sector.

\section{Acknowledgements}

This research is financially supported by the GUANGZHOU MUNICIPAL GOVERNMENT. 


\section{References}

[1] Yang Liu: Electricity Price Regulation in the EU, Germany and China, AVM Munich 2013, p. 175.

[2] Yang Liu: Research of the Direct Power Purchase in China, Journal of China University of Geosciences, 2013:14 (5) p.68.

[3] Yang Liu: Cost Orientation of the Grid Charge, AVM Munich 2012, p. 28.

[4] Yang Liu: Cost Orientation of the Grid Charge - Legal Comparison of the EU, German and Chinese Energy Laws, AVM Munich, 2011, p. 52.

[5] Yang Liu: Online Finance: Regulatory Regime Reform in China, US-China Law Review, 2015:4 (112) p.328.

[6] Yang Liu: Universal Service: Necessary Constitutional Provisions for the Reform in the Chinese Electricity Industry, US-China Law Review, 2015:5 (113) p.427.

[7] Yang Liu: On the Possibility to Replace Ladder-type Price with Electricity Consumption Tax, Journal of Nanjing University of Technology, 2013:12 (1) p.56.

[8] Marco Herrmann, Das US-amerikanishe Energierecht am Beispiel Kaliforniens, Germany, CHV 2005, P.133.

[9] Schmidt-Preuss, Matthias: Brennpunkte des neuen Energiewirtschaftsgesetzes, im Geis, MaxEmanuel/Umbach, Dieter C.: Plannung - Steuerung - Kontrolle, Berlin 2006, 573-585.

[10] Lan Peng, On the Principles of Regulation System in China, International Journalists, 2007/11, p.16.

[11] Säcker, Franz Jürgen: Die wettbewerbsorientierte Anreizregulierung von Netzwirtschaften, N\&R 2/09, 81-85.

[12] ERGEG (European Regulators Group for Electricity \& Gas): Draft Guideline of Good Practice for Operating Security, Ref: E08-ENM-02-04, 10th April 2008, 3-15. 